\title{
Some Aspects Regarding the Transhumance of the Romanian Beekeepers, Members of the Black Sea Basin Network
}

\author{
Ionica Soare $^{\star}$
}

\begin{tabular}{l}
\hline \multicolumn{1}{c}{ A R T I C L E I N F O } \\
\hline Article history: \\
Accepted November 2020 \\
Available online December 2020 \\
\hline JEL Classification \\
013 \\
Keywords: \\
The South East Development \\
Region, The beekeepers'network, \\
The capitalization of the \\
melliferous potential, \\
Transhumance/pastoral \\
beekeeping, Support, beekeepers' \\
activity, Digital maps \\
\hline
\end{tabular}

\begin{abstract}
A B S T R A C T
The paper focuses on aspects from the activity of the beekeepers from The South East Development Region of Romania, members of the beekeeper's network from the Black Sea Basin Region. It focuses on the capitalization of the melliferous potential from this region in terms of presenting the plants for beekeeping harvests as well as the areas favourable for transhumance. There is an emphasis on the size of the area dedicated to transhumance as well as on the intensity of this phenomenon especially for the plants with high and very high beekeeping share (white acacia, lime and sunflower). Furthermore, there is a presentation of the frequent issues that the beekeepers face in their activity (especially in transhumance) and possible solutions foreseen after the present study. Thus, the paper presents the making of an application based on digital maps of the areas of apiculture interest, a tool that comes to support the beekeepers, especially during the thanshumance period.
\end{abstract}

(c) 2020 EAI. All rights reserved.

\section{Introduction}

It is wellknown that bees and nectar-poliniferous resources from the spontaneous and grown flora are key elements in the beekeeping activity (Lazar \& Vornicul, O. C. 2007). Many members of the human communities depend on these biological resources on which their traditional way of life are based, representing their own business. Romania has a long tradition in apiculture (Iordache et. al, 2007), presenting a high potential for the organic honey production, due to the favourable conditions for Apis mellifera carpatica, defined as a self-contained species for more than 55 years in our country (Grigoras, 2018). Also, The South East Development Region of Romania presents a high apicol potential, offering many and variate regions for pastoral beekeeping. In this work we present some aspects regarding the activity of the beekeepers from this region, members of the beekeeper's network from the Black Sea Basin Region. We present the melliferous resources, consisting in the plants for beekeeping harvests as well as the areas favourable for pastoral beekeeping. For supporting the beekeepers in solving some of the issues encountered especially in transhumance, we present an application based on digital maps.

\section{Materials and methods}

The study has been achieved on the basis of the questionnaire applied to the Romanian beekeepers, members of the network of beekeepers from the Basin of the Black Sea Region, on the analysis and interpretation of the data centralized from the questionnaires, completed with information from the speciality literature. These data were collected during the implemenration of the project "Increase trading and modernization of beekeeping and connected sectors in the Black Sea Basin" ITM BEE-BSB, BSB136 (https://ems-bs.mdrap.ro/app/main?execution=e1s1; https://www.tehnopol-gl.ro/ro), This project was sustained through the Common Operational Programme - the Basin of the Black Sea 2014-2020, co-financed by the European Union through the European Tool of Neighbourhood and by the participant countries (Bulgaria, Moldova, Turkey and Ukraine), implemented by The Tehnopol Galati Association in March 2019.

Throughout most part of this paper, the data from the questionnaires filled in regarding the location of the apiary during the beekeeping inactive season and out of the pastoral beekeeping period / transhumance; the host localities / places with temporary hearths from the transhumance route as well as the issues the beekeepers have frequently dealt with in the last years in order to identify and highlight: 
* the honey plants for the harvests of maintenance of the bee families as well as of the areas favourable for the transhumance.

$\star$ the size of the transhumance area, the length of the transhumant route between the host localities from the thranshumance and the localities where they have the apiary;

* the effort made by the beekeepers for this traditional occupation - beekeeping;

* the beekeepers'major issues some of which constitute shortcomings of Romanian beekeeping and other disfunctions in the beekeepers' work in the development of their business.

The final part of the paper captures aspects from the project activity for the benefit of the beekeepers and beekeeping.

\section{Results and discussions}

The network of beekeepers of the Basin of the Black Sea Region is young and hopefully in a countinuous forming through the implementation of the project (starting from March 2019). Apart to the Romanian participant (through the Tehnopol Galati Association - project leader) the other four partners are: The Agency of Economic Development Varna, Bulgaria; The Development Agency East Black Sea, Turkey; The Business Centre Cahul, Moldova; The Regional Board of Trade and Industry /The Regional Chamber of Commerce and The Industry Mykolaiv, Ukraine. The Romanian part succeded to attract in short time near 100 beekeeper's members, who responded to previously mentione questionares. One can argue that this number is small for performing a statistic; despite of this, considering the variety of the aspects reported by the responders, we consider that this number represents a statistically representative sample.

A) Aspects that target the location, the settlement locality of the apiary during the inactive beekeeping season and out of the period of pastoral / transhumant apiculture.

Regarding the declaration of the dwelling on counties and mediums the results have been: $87 \%$ of the responders live in the counties Braila (49\%) and Galati (37\%) and 65\% of the total of the responders in urban area; most responderers have ages of over 50 years (some with tradition passed from generation to generation), few are beginners and young.

Regarding the declaration of the locality where the apiary is settled not only during the inactive beekeeping season period (late autumn, winter and early spring), but also out of the beekeeping / apiculture harvest period which requires pastoral / transhumant beekeeping, the following aspects have been noticed:

a. from the total of responders (100\%) only $95 \%$ have the apiary located in the rural area;

b. $\quad 8.86 \%$ of the responders have family business, that is why the number of apiaries is a little decreased in comparison with the total of responders (94.93\% apiaries from $100 \%$ responders).

c. for most of them (94.2\%) the dwelling county coincides with the county where they have the apiary placed; in the opposite situation, the counties in which the apiaries are located belong to the South East Development Region and are neighbouring counties for the dwelling county (e.g. residence in Braila and the apiary in Tulcea county or the residence in Buzau and the apiary in Braila county, near Braila town) only to be closer to the areas that constitute main or maintenance harvests;

d. the existence of two sets of 'satellite' villages both around Braila (12 villages) and Galati ( 9 villages) each registered within a radius of about $50 \mathrm{~km}$ compared with the dwelling town or the "bedroom" town, for those $87 \%$ of the responders and who together with the towns enumerated constitute the main poles of the frequent shuttle in supporting and developing their business and at the same time the beekeeping sector; for some beekeepers the village represents : the native village, the location of the apiary being the yard of their parental home or a relative's or friend's house.

e. the villages mentioned as locations of the apiary function as 'host villages' not only during the period of the inactive beekeeping season (late autumn, winter and early spring) and of transhumance, but also in the active season through the capitalization of the melliferous base, even for the plants with very high and high farming / agricultural weight (acacia, lime or sunflower)

Among the responders, the size of the apiary/ beekeeping exploitation and the number of the bee families / person varies from 2-3 bee families at young beginners to 300 bee families at those with seniority and experience. The average number of bee families/member of the network of the Basin of The Black Sea Region is of about 40 bee families thus, on the whole, it gets to a total of 4000 bee families representing almost $30 \%$ of the total number of bee families (11837 bee families) (INSSE) of Braila county in 2019, the county with the lowest number of bee families from the South East Development Region.

\section{B) Melliferous plants}

From the questionnaires result the following honey plants that constitute the maintainance and production harvests: willow (from those with early blooming in spring,especially ensuring the maintainance harvests of bee family), the hazelnut tree from deciduous forests, corn, fruit trees, autumn rape (in the season when the flora is very poor and covers the created void), the acacia (represents the first production harvest), coiander, amorphous, lime, sunflower (the last two belonging to the predominant summer harvests), plants from flood / floodable areas (including autumn in the meadows of the main rivers Siret, Prut, Buzau and the swamps from the Danube Delta); as well as various plants within the meadow category. 
The rendering of honey plants in a certain order, as much as possible (even though there are overlaps during blooming), comes to signal the sequence of blooming throughout the beekeeping active season, almost the same every year, and thus the practice and development of beekeeping.

There are plants from the spontaneous and grown flora and after the biological and economic classification from the trees and shrubs (native and introduced), spontaneous herbaceous plants (as the ones from forest, meadows and fields, the ones that appear spontaneously in agricultural / farming crops, etc), grown plants that comprise technical plants, aromatic medicinal plants and characteristic honey plants, fruit trees (INSSE; Alexandru et. al, 1986; Vizireanu, 2020).

From the honey plants mentioned above five of them - acacia, lime, sunflower, the vegatation from the floodable areas, hill meadows- constitute the main harvests at the level of Romania (according to Cirnu,1980; Lazar 2020) along with other two honey plants - fireweed and raspberry - but also present (Iordache et al, 2007) in the South -eastern Development Area (with unfolding in the area of the Black Sea in the east until the bend / curvature of the Oriental Carpathians, in the west of it), right because of the diversity of the relief and the ecopedoclimatic conditions / circumstances that influence its structure and the capitalization of the honey potential.

At the level of all Romanian beekeepers registered in the network of The Region of the Basin of The Black Sea, including the ones questioned, the acacia, lime, sunflower constitute the main harvests.

The geographical distribution of the honey plants (through diversity and richness) from the Region of South - East Development and the wish to found a business and its development without too high costs, combined sometimes with the passion or the need to get an additional income, engendered the type of pastoral / transhumant beekeeping, practiced by most beekeepers from the network.

B.1) The period May - June is for beekeepers, the harvest for the white acacia (Robinia pseudoacacia. Scientific name) or Black locust, species almost naturalized all over the European continent (Nicolescu et al., 2018) and non - indigenous of Romania (in 1852 the first plantation) and which is found with a frequency of $50-70 \%$ and even over 75\% (Sitzia et al, 2016) within the forests / peaks from the Region of South East Development; practice has proved that when it is planted in mixed cultures, the other species must be grouped, or else the white acacia eliminates them (Ciuvat et al, 2013).

The annual and abundant blooming in May-June lasts (after the prognosis of the blooming phase of the white acacia in favourable years) about two weeks for the acacias on the peaks. But the ecopedoclimatic conditions imposed by general and local factors inflence the blooming moment and its duration (it can last about 10 days at solitary acacias and a few days more at the ones on the peak), differentiating at the level of the „, big acacia areal” outlined in the east of the country, according to the geographic distribution on the main forest areas at the level of the country (Ciuvat et al, 2013).

Thus, in the assemble of this big acacia areal (registered counties from the South East Development Region) the extension of the sequence of blooming phenophase on the basis of ecopedoclimatic differences determines the growth/increase of the duration of production of acacia honey and is the basis of the onset and intensification of the phenomenon of pastoral / transhumant beekeeping. Frequent in the beekeepers' language are the notions Acacia1, Acacia 2, Acacia 3. It is worth saying that the white acacia is a honey, nectarifer and mana manufacturer species with very high economic beekeeping proportion. The speciality literature specifies for favourable years, high values for the assessed honey production (kg / ha). Regularly between $900-1500 \mathrm{~kg} / \mathrm{ha}$ at trees on peak and 34- $39 \mathrm{~kg}$ of honey on bee family, under temperature conditions of $20^{0}-30^{\circ} \mathrm{C}$, atmospheric pressure $760 \mathrm{mmhg}$, the air humidity $70-80 \%$, light wind under $2 \mathrm{~m} / \mathrm{s}$ and weak precipitation. (Iordache et al, 2007).

Following and analysing the localities (name, geographical location) reported in questionnaires by beekeepers in which they settled the apiary/ apiculture / beekeeping exploitation with the purpose of the capitalization of acacia harvest it results the following situation:

* are predominant the localities from the county in which they reside or where the keep their apiary settled during the winter;

* pastoral and transhumant beekeeping is practiced not only within the counties in which they reside, and also beyond the limits of the South East Development Region, regularly the ones that have a bigger beekeeping exploitation (of over 100 bee families) and favourable / advantageous transport possibilities (Table 1);

* the localities that are chosen for beekeeping exploitation are the ones that have areas of ground with light soils, surface groundwater, which are near rivers / lakes because the honey production is higher at hectar (100 - $1700 \mathrm{~kg} / \mathrm{ha}$ ) as for example / such as Varsatura, Sutesti, Ramnicelu (Braila county).

* the sequence of phenophases (white acacia 1, white acacia 2, white acacia 3) at the expense of the spatial differences of ecopedoclimatic nature correlated with the wish to increase the honey production, determines longer routes of transhumant beekeeping of over $300 \mathrm{~km}$ between the overwintering place and the maximum achieved point; example : Valea Canepii (place for apiary during the winter) - Insuratei (Braila county) - Beresti (Galati county) - Bacau area (Bacau county).

The white acacia is a sun - loving species with little tolerance for the shade, grows well in regions with long and hot summers on a great variety of soils, does not prefer the regions areas with early freezing, but has 
a fast increase and vigorous regeneration sometimes invading the fields (Ciuvat et al, 2013) favourable to increase and development. In the context of climatic changes, the importance of adjusting this species to poor soils with high temperature (e. g. sand dunes) is expected to grow (Nicolescu et al, 2018).

Table1. The "host localities" for the pastoral beekeeping.

\begin{tabular}{|c|c|c|c|c|c|c|c|c|}
\hline \multirow[t]{2}{*}{$\begin{array}{l}\text { The } \\
\text { name of } \\
\text { the } \\
\text { mellifero } \\
\text { us plant }\end{array}$} & \multicolumn{2}{|c|}{ For the beekeepers that live in $\mathrm{Gl}$} & \multicolumn{2}{|c|}{$\begin{array}{l}\text { For the beekeepers that live in Braila } \\
\text { county }\end{array}$} & \multicolumn{2}{|c|}{$\begin{array}{c}\text { For the beekeepers } \\
\text { that live in Vrancea } \\
\text { county }\end{array}$} & \multicolumn{2}{|c|}{$\begin{array}{l}\text { for the beekeepers in } \\
\text { Buzau county }\end{array}$} \\
\hline & within Galati county & $\begin{array}{l}\text { in other } \\
\text { counties }\end{array}$ & Within Braila county & In other counties & $\begin{array}{l}\text { Within } \\
\text { Vrancea } \\
\text { county }\end{array}$ & $\begin{array}{l}\text { In other } \\
\text { counties }\end{array}$ & $\begin{array}{l}\text { Within } \\
\text { Buzau } \\
\text { county }\end{array}$ & $\begin{array}{l}\text { In other } \\
\text { counties }\end{array}$ \\
\hline acacia & $\begin{array}{l}\text { Valea lui Mihai, } \\
\text { Malul Alb, Cuca, Berești, } \\
\text { Suceveni, Jorăști, Liești, } \\
\text { Cudalbi, Pădurea } \\
\text { Gârboavele (lângă } \\
\text { Galați), Smârdan }\end{array}$ & $\begin{array}{l}\text { Bacău } \\
\text { county : } \\
\text { Motoșeni }\end{array}$ & $\begin{array}{c}\text { Însurăței (Pădurea } \\
\text { Viișoara), Bărăganu, } \\
\text { Bertești, Râmnicelu, } \\
\text { Scorțaru Nou, } \\
\text { Scorțaru Vechi, } \\
\text { Colțea, Șuțești } \\
\text { (pădurea Camnița), } \\
\text { Vărsătura }\end{array}$ & $\begin{array}{l}\text {-Galați county: } \\
\text { Cuca, Târgu } \\
\text { Bujor, Berești; } \\
\text {-Buzău county: } \\
\text { Livada; } \\
\text { Bacău county: } \\
\text { Bacău }\end{array}$ & - & $\begin{array}{l}\text { Brăila } \\
\text { county: } \\
\text { Scorțaru } \\
\text { Nou }\end{array}$ & - & $\begin{array}{l}\text { Galați } \\
\text { county } \\
\text { Berești }\end{array}$ \\
\hline lime & $\begin{array}{c}\text { Adam, Buciumeni, Gl } \\
\text { (zona Gradinii Publice) }\end{array}$ & $\begin{array}{l}\text { Tulcea } \\
\text { county: } \\
\text { Luncavița } \\
\text { Niculițel } \\
\end{array}$ & - & $\begin{array}{l}\text { Tulcea county: } \\
\text { Greci, Luncavița, } \\
\text { Revărsarea }\end{array}$ & - & $\begin{array}{c}\text { Tulcea } \\
\text { county : } \\
\text { Greci }\end{array}$ & - & $\begin{array}{l}\text { Tulcea } \\
\text { county: } \\
\text { Greci }\end{array}$ \\
\hline $\begin{array}{c}\text { Sunflowe } \\
\mathrm{r}\end{array}$ & $\begin{array}{l}\text { Vasile Alecsandri, } \\
\text { Slobozia Conachi, Cuca, } \\
\text { Schela, Băleni, Oancea, } \\
\text { Vânători, Frumușița, } \\
\text { Ijdileni }\end{array}$ & & $\begin{array}{c}\text { Albina, Vădeni, } \\
\text { Măxineni, Valea } \\
\text { Cânepii, localități din } \\
\text { Insula Mare a Brăilei, } \\
\text { zona Brăilei, Scorțaru } \\
\text { Nou, Racoviță, } \\
\text { Unirea; Dedulești, } \\
\text { Scorțaru Vechi, Lacu } \\
\text { Sărat }\end{array}$ & $\begin{array}{l}\text { Buzău county } \\
\text { :Amara }\end{array}$ & - & $\begin{array}{l}\text { Brăila } \\
\text { county: } \\
\text { Scorțaru } \\
\text { Nou }\end{array}$ & - & $\begin{array}{l}\text { Brăila } \\
\text { county: } \\
\text { Latinu }\end{array}$ \\
\hline
\end{tabular}

B.2) After the end of the blooming of the acacia, at about 20 days in favourable years (from a meteorological point of view) the beekeepers start the main harvest of the acacia.

Within the limits of the South - eastern Development area and its surroundings, corresponding to the eastern end of the big native region of Europe (Caudullo et al, 2017; Eaton et al, 2016) and where beekeeping is practiced, the lime is represented through the species:big-leafed lime (Tilia platyphyllos), shiny/ glossy small-leafed lime (Tilia cordata), silver lime (Tilia tomentosa) which can be found separately, together or mixed with other species of broadleaf trees, such as oak, hornbeam, evergreen oak, etc. On the whole, within the associations, they participate in different proportions, reaching $90 \%$ or forming pure tree as in the north of Dobrogea (e.g. Niculitel Forest, natural area of national interest in the year 2000 with a surface of 11 ha); these three species together form in Dobrogea the widest compact area of lime from the country (since 1989 the area occupied by lime in Tulcea country has been increasing - holding 18713 ha then) (Iordache et al, 2007).

The same as the white acacia it is a honey,.nectarifer and mana making with a very high economic bee-keeping rate (only the silver lime) .

The harvest lasts depending on the annual blooming that starts in the second part of May with the big-leafed lime 8-15 days and then in June the shiny / glossy lime with 8-10 days followed by the silver lime 7-12 days (Iordache et al, 2007). Along with the great duration of the blooming of the three species of lime taken together of about 30 days and the honey production per hectar is pretty high; for the big-leafed lime $800 \mathrm{~kg} / \mathrm{ha}$; for the shiny / glossy lime of $1000 \mathrm{~kg} / \mathrm{ha}$, for the silver lime - 1200kg / ha in normal climate conditions (Manualul apicultorului, 1986; Iordache et al, 2007).

On the basis of the analysis of the localities reported in surveys in which they settled installed their apiary for capitalizing the lime harvest it emerges:

\# only transhumant shepherding is generated for over $50 \%$ of beekeepers (Table 1 );

$\$ 51 \%$ of the total of beekeepers (with $52 \%$ apiaries of the total number) arrive in Dobrogea, of which: $26.58 \%$ beekeepers (with $25.33 \%$ apiaries of the total) from Brăila, county; $11.39 \%$ beekeepers (with $10.66 \%$ apiaries of the total) from Gl county; the preferences are for the localities Luncavița (20.25\% beekeepers with $17.33 \%$ apiaries) and Greci; 
* almost $60 \%$ of the beekeepers from Brăila county practise transhumant shepherding in Tulcea county, Brăila being deprived of lime massives.

$\$ 3.79 \%$ of the beekeepers who live outsid Braila county and keep their apiaries in localities near Braila during winter in order to reduce the time, effort and costs for the transhumance in Dobrogea;

* Gl figures as the only county within which transhumance is practised only by few beekeepers. (13.33\%).

B.3) The third main harvest of the Romanian beekeepers from the network of the Black Sea Basin and as well as for the third honey plant with very high beekeeping proportion (alongside the acacia and silver lime), from the four taking into consideration throughout Romania (Iordache et al, 2007) (depending on the economic outcomes obtained in apiaries and beekeeping exploitations) is the sunflower. The sunflower (Helianthus annuus L, its name in Latin) is a herbaceous, technical plant, with tradition in Romania and honey making as well (nectar, plliniferous for mana and propolis), grown annually, blooming in June - July with a duration of 20-30 days and a production of honey evaluated in favourable conditions of 34-130 kg / ha. As in the case of white acacia, in order to increase the production of honey on the account of the extension of the duration of blooming in the beekeepers' language appear the notions sunflower 1 and sunflower 2, as different places /soles for the apiculture exploitation.

On the basis of the localities, reported in surveys, in which they settled their apiary / beekeeping exploitation in order to capitalize the harvest of sunflower it emerges:

* the beekeepers practise not only the transhumant beekeeping but also the beekeeping in the area in which they live and / or keep their apiary outside the transhumance period during winter and the beekeeping season;

* an intercounty transhumant beekeeping in proportion of $97 \%$ for beekeepers (almost $60 \%$ of all those surveyed) that resort to this form of beekeeping (Table 1);

* preference for this honey plant through lower costs regarding the length of the transhumant route, the honey performances of the hybrids of sunflower, the density of plants per hectar, the extremely large areas within the South East Development Region and ecopedoclimatic factors on whose basis they can extend the harvest (sunflower 1, sunflower2) for enhancing the honey production, the longest transhumant route from the locality in which they keep their apiary (in winter and in the beekeeping season outside the transhumance) up to / as far as the locality chosen for beekeeping exploitation, even if the neighbouring county reaches $100 \mathrm{~km}$.

From Fig. 1 it emerges that the areas grown with sunflower, generally being in a continuous growth from 1990 till the end of the year 2019 at the level of the counties in which the beekeepers practise their pastoral activity developing their business, especially Braila and Galati counties. There has been such a huge honey potential put at the beekeeper's disposal, that even for those who resorted to the transhumance in the Great Island of Braila (nationally recognised as important agricultural area), the ferry crossing over the Danube has not been an impediment any more, the beekeepers being pecuniarily rewarded by the native agricultural farmers for the pollination of the fields of sunflower that they own.

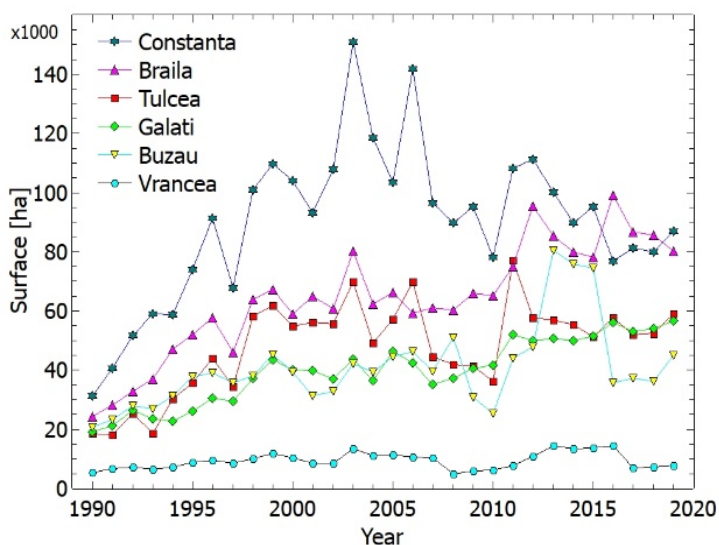

Figure 1. The area cultivated with sunflower (th /ha) on the counties of the South -East Development Region

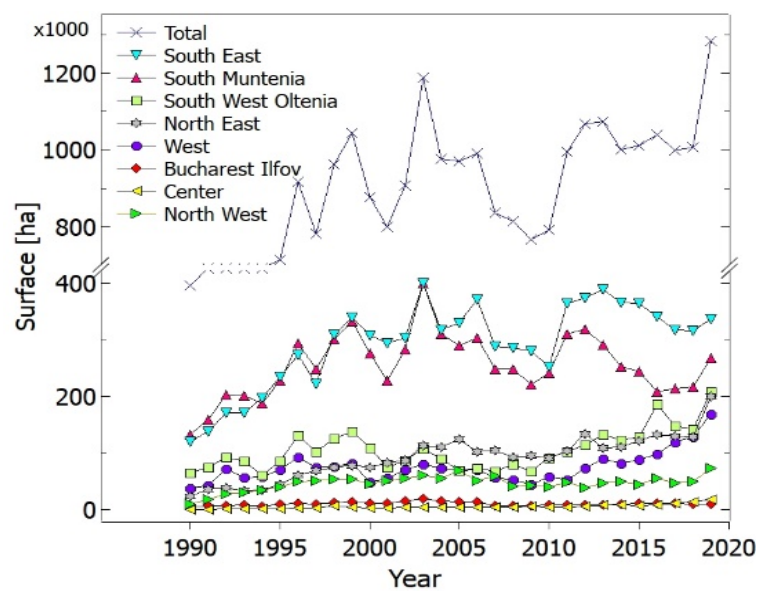

Figure 2. The area cultivated with sunflower (th/ ha)- total country and the development regions of Romania

Source: http://statistici.insse.ro; activated site 30 $0^{\text {th }}$ October 2020

The South - Eastern Development Region (Fig.2) has come to represent through the cultivated area in 2019, over a quarter of the country surface, since 1990, being almost permanently on the first place among all the development regions of the country, standing out even more in the last ten years in comparison with South Muntenia Development Region. 
The extension of the areas with sunflower in this development area, as well as at national level, was due to the research carried out in Romania within a lot of series of experiments, some with international collaboration within Sunflower FAO Network, which highlighted the necessity of obeying the important elements of an advanced farming technology (Csep, 2018); the fluctuation of the values of the cultivated areas can be put among others, on the account of the rotation as a highly important measure (Csep, 2018), but also on the account of the increase of Romania's export of sunflower seeds in the last years (Kaya, 2014).

The South East Development Region represents the most favourable area for this crop at the level of the country, being a great honey potential with the highest and most stable honey productions per bee family (of up to $30 \mathrm{~kg}$ ). This explains why it is "host" for beekeeping exploitations of a lot of beekeepers from other development regions of the country (even from the north of the North - East Development Region) during the capitalization of the harvest of sunflower.

For the other mentioned melliferous plants at the expense of whose harvests of production and the maintance of bee families are developed -not only pastoral beekeeping / transhumance (within county and intercounty) for most of them, but also stationary shepherding - the situation has been expressed by the responders as follows: the hazelnut - $1.26 \%$; amorphous -8,86\%; coriander - $7.59 \%$, corn - $1.26 \%$; meadow - $7.59 \%$ (with intercounty transhumance of up to $141 \mathrm{~km}$ between Schela, Galati county and Campuri, Vrancea county); mint - 6.32\% (with transhumance within the county of up to $75 \mathrm{~km}$ ); swamp plants - $2.53 \%$; fruit trees $-2.53 \%$; rape $-21.51 \%$ (with intercounty transhumance of up to $60 \mathrm{~km}$ between Surdila Gaiseanca - Braila county and Valcele - Buzau county); willow $-5.06 \%$.

The beekeepers sell their honey with labels such as "lime honey", "acacia honey", "sunflower honey", "meadow honey", "poliflower honey". The justification has come on the account of the location chosen for the beekeeping exploitation.

This analysis highlights the fact that the South East Development Region disposes of a pretty high melliferous potential with areas favourable for pastoral beekeeping / transhumance. Most responders (98.73 $\%$ ) conduct their apiculture activity within this region through the complimentary character of the component counties for the completion of the beekeeping production and maintenance harvests throughout the beekeeping season. The South East Development Region has come to register in 2019 the highest number of bee families from those 8 development regions of Romania (17.56 \% of total country) (INSSE). It should be reminded that the area cultivated with sunflower in the development area under discussion has been situated on the first place for more than 10 years. Through the bees, the saturated and oversaturated pollination is sustained, they being an economic force between the production and the beekeeper.

The capitalization of the melliferous potential within the South East Development Region benefits the beekeepers -in this case the transhumance does not require additional expenses, bigger effort and more time as when it comes to the beekeepers with the residence and the apiary location in other counties or regions during winter (e.g. Suceava) and which appeal to a long transhumant way up to this region.

\section{C) Issues they have faced}

After questioning the beekeepers taking part at the above mentioned project, there has been a selection of the problems they have faced in the last years. It is worth mentioning that stating the problems has been done spontaneously by the beekeepers according to the importance given by the responderer, reflecting his /her degree of beekeeping experience and professional training. The problems expressed by them have been grouped in order to highlight some aspects that should be taken ino consideration by the main actors from the beekeeping / agricultural, forestry and administrative sector. Thus, the following categories of issues have been identified.

Not announcing the performing of chemical treatments (along with the name of the product used) at agricultural and forestry crops in due time (expressed by $32.5 \%$ of the responders).The rift created by the local councils and beekeepers in transmitting the announcement regarding the application of chemical treatments by the owners of farmlands and forests and even delaying their transmission have led to : i)the death of a great number of bee families; some beekeepers have pointed out that they were about to lose their business / work; ii) creating panick and time crisis situations of removing the apiary from the land subjected to chemical treatments. It is not only because of the non-involvement of the local councils in time, but also of the people in charge of the beekeepers' associations; in many cases the city councils made the announcement at the headquarter of the beekeepers' associations. An alert message received by phone would solve the problem.

The unfavourable weather (expressed by $44.39 \%$ of the responders) with impact on : i) reducing the duration of blooming/ reducing the harvest period especially for acacia (for example in 1919) or lime, and obviously on the honey production; ii) on some outside roads becoming impracticable making difficult the field movement of the apiary; sometimes it has got to the point of getting stuck; iii) on the health state of the bee families through the sudden temperature drops throughout the transhumance; some beekeepers have lost bee families; iv) on the beekeepers'health.

The high ferry fare and difficulties in transport (expressed by $5.2 \%$ of the respondents). 
The transhumance in Dobrogea, over / across the Danube supposes: i) for the time being, till finishing and putting into service of the bridge within the area Br-Macin, the beekeepers' adjustment to the working programme around the clock and the fares applied differently; the high fare during the night, exactly the period considered by the beekeepers favourable for the tranportation / removal of the apiary on intercounty roads, and during the day because of the high capacity of the apiary and of overcrowding (cars and people); ii) the difficulty in getting on the ferry and taking the apiary out of the ferry; iii) delays generated by the infrastructure at the crossing points from Braila or Galati (number of ferries, their capacity, mooring piers/docs, boarding platforms on both banks,etc), by weather conditions and high levels of the Danube especially in spring, but also by crowds; iv) the selection / choice of the alternative across the bridge from Giugeni - Vadu Oii which would involve extending the route especially for the beekeepers from Braila, Galati, Vrancea, additional expenses.

Overcrowding due to not obeying the distance between apiary hearths (expressed by $10.3 \%$ of responders). Sometimes it gets to this situation regulated by the laws in force (Law no. 79/2020), because of: i) the malfunctioning management at the level of the public local authorities and the owners of agricultural and forest lands; ii) some beekeepers' own initiative who willingly or unknowingly break the established plannings. The application made (see the digital maps) could be a useful tool in solving such issues.

The lack of honey tree species/lack of lands with honey basis (expressed by $5 \%$ of responders). The reference has been made to : i) the very low density of honey trees (species of acacia and lime) in built-up areas either because of cutting them down (in the case of withered trees or for heating the dwellings) or of non-planting; ii) the lack of forest curtains (white acacia), whose presence would protect the bees against the wind and would be important for the capitalization of the harvest; iii) the non-valorization of the lands unsuitable for agriculture or the lands from the meadow areas, which could be forested with honey species.

The appearance of self-pollinating plants (expressed by $5 \%$ of the responders) .

Their existence among the hibrids of sunflower highlights the pastoral shepherding through the reduction of the sunflower area recognised so far with importance in beekeeping for the main harvest.

Administrative problems (expressed by $8.5 \%$ of the responders). The things pointed out have been connected with : i) the precarious organisation of pastoral beekeeping by the authorities of the local public administration or of some protected natural areas and by the owners of agricultural and forest lands; ii) noncommunicating in written form to the authorities of public local authorities about the site of the apiaries (in pastoral and winter period) and of some details (number of bee families, the owner's name); these errors are generally specific to beginner beekeepers.

Problems connected with the retail activity (expressed by $10.2 \%$ of the responders) have refered to :

I. maintaining the low price of honey and the other beekeeping products which does not compensate for the material and physical effort and does not stimulate, in many situations, the development of the business (the increase of the number of bee apiaries etc). For example, the price of the honey (such as sunflower or polifloral) is generally comparable with the one of the unrefined raw sugar (commercial product). This aspect arises from the weak education of the population reflected in the much lower consumption per capita in comparison with the countries from the north.

II. the lack of a marketplace for great quantities of honey reduces the development of the business; many beekeepers limit the development of the business, produce honey quantities that ensure their own consumption / for their family and as much as they can sell in the local selling points (e,g. at the stalls from the agrifood markets) or to friends / aquaintances.

The lack of an automatic line of bottling (expressed by $1.7 \%$ of the respondents). The automatic bottling of the jar of honey as well as the existence of a warehouse for keeping it in proper conditions are requests that impose themselves in order to maintain the quality of honey in time. Even if this problem has been signaled at that moment (when filling in the questionnaire) by a small number of beekeepers, it is a common one for an association / associations of beekeepers.

Problems connected with the grants from the state_(expressed by $1.7 \%$ of the rersponders). Aspects regarding the reduced number of grants have been targeted (consisting in small sums), short terms for the submission of the documents needed for granting, non informing in due time, bureaucracy, plenty of applications and overdrafting fund.

D) Supporting the private beekeeping sector through the elimination / diminishing some difficulties / gridlocks on the network members'account

Through the implementation of the project (in proportion of $70 \%$ by the end of the year 2020) there has been a solution for the set of needs identified as priorities directly related with the increase of competitiveness and viability of the activities from the beekeeping sector within the South East Development Region, especially from the rural space, and of the trade. Obviously, the addressing has been made directly and immediately to the beekeepers registered in the network of the Region of the Black Sea Basin (RBMN). Generally, we can discuss about a congestion of hardships and gridlocks that the beekeepers used to deal with, not only those with experience but also the beginners, through the implementation of a series of actions/ activities corresponding to the purpose of the project. 
D.1) The activities related with the ensuring of the transfer of knowledge and innovation, organised and unfolded/elaborated in order to improve the beekeepers' competences and knowledge, of the economic performance for a better insertion on the market, have gradually brought visible progress in their activity, making them more confident in their own forces and even more sociable. Among them, are worth mentioning the following: the Course of training and professional shaping, the study "The honey potential, the climatic conditions, the air and soil quality in the Region of the Basin of the Black Sea, the beekeeping guide, open / demonstrative lessons (e.g. techniques in harvesting / collecting bee venom), attending beekeeping fairs (e.g. the one from Varna frpm August 2019 which was attended by Romanian beekeepers, members of RBMN network.), etc.

D.2) The development of the services of using the Information Technology and Communication_was not missing from the beekeepers 'personal development.

The design of digital maps with the purpose of developing and modernizing the businesses from the beekeeping sector, and of supporting in their work the beekeepers from the network registered in the Area of The Black Sea Basin have had a special, attractive and exciting impact on them. They have been made of the National Institute of Research - Development in Silviculture "Marin Dracea" from Bucharest; designing the data base has been made in ArcGis environment taking into account the aim of the project. At present, the web-GIS application (Fig. 3), which contains digital maps and additional information, is found and can be downloaded from the site https://ro.beekeeping-bsb.net/harti/

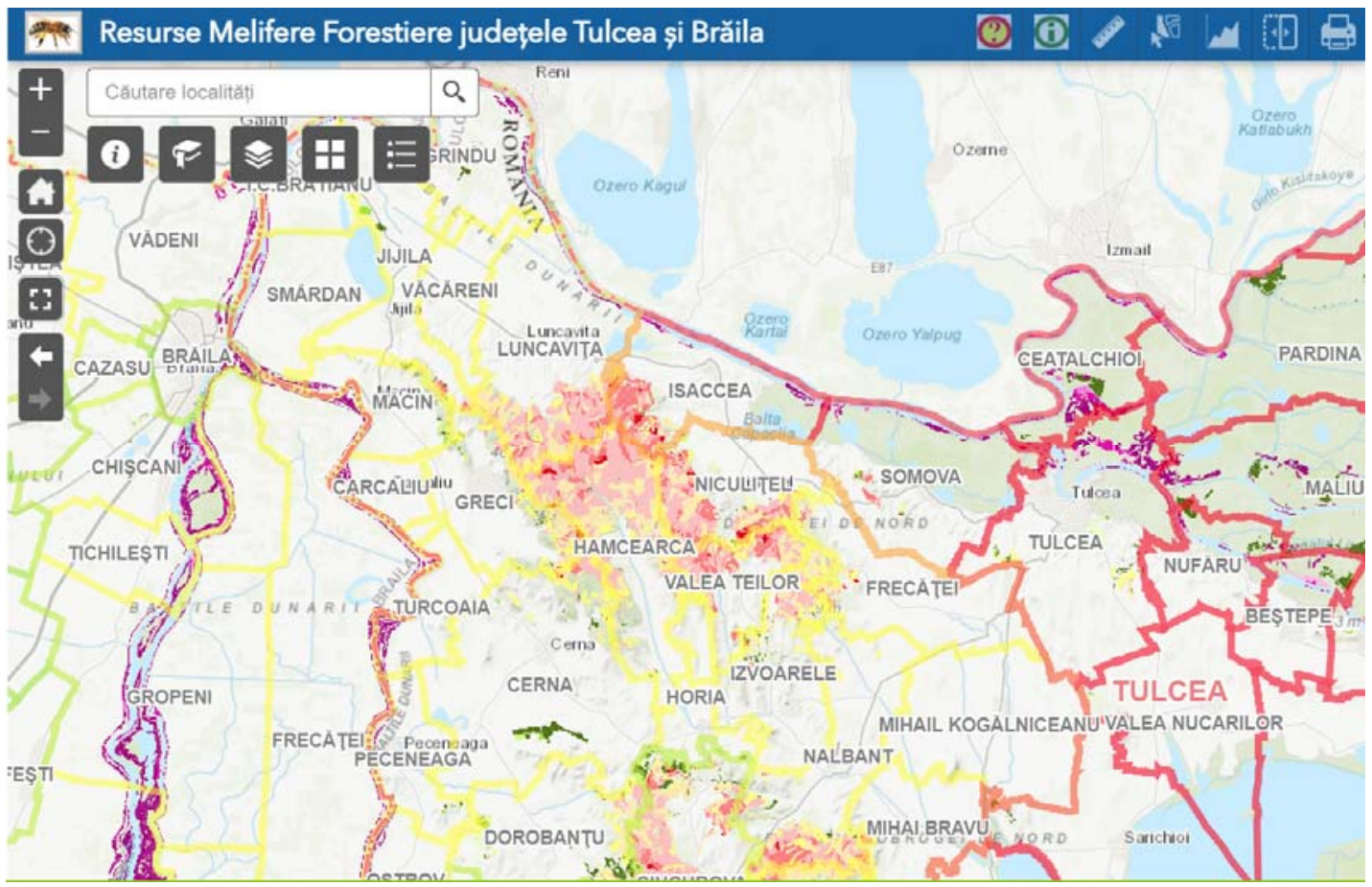

Figure 3. Image referring to the web-GIS application of the forest surfaces / areas from Tulcea and Braila counties which contain species of honey trees (lime, acacia and willow)

Through their complex and updated content, digital maps surpass a lot the classic maps (Iordache et al, 2007) and have been focused on the localization of the main peaks of acacia and lime from Romania (including for Braila and Tulcea), being essential tools in the beekeepers' field activity so far.

Digital maps comprise the following basic / essential elements connected in a relational system within Braila and Tulcea counties: 3 honey plants that contribute to the beekeeping harvests and of maintaining of bees, communication ways (public roads and forest tracks), waters (flowing waters, channels / canals water areas/ lakes reach / body of water), the limits of the administrative - territorial units, the limits of the protected natural areas, disadvantaged areas (extracted from "the National Programme of Rural Development 20072013", version consolidated in November 2013 (PNDR 2007-2013).

The fields of data and information regarding the honey plants from the forest fund of Braila and Tulcea counties (managed by RNP-ROMSILVA through forest organizations) - white acacia (Robinia pseudoacacia l - scientific name), lime with big leaf (Tilia platyphyllos), shiny lime with small leaf (Tilia cordata), silver lime (Tilia tomentosa), Willow (Salix Alba L) -comprise the geographical distribution, the average altitude of the relief, the exposition of the land, the average slope, the average age of the honey species, the area occupied, the age percentage (under 40 / over 40 , under 10 years / over 10 years respectively). 
In this way the beekepers have the possibility to perform simple and complex operations. Thus the following are ensured:

* the better and successful capitalization of the tree honey potential especially for beekeepers that practise pastoral / transhumant apiculture (including for those focused on ecological apiculture) connected with knowing the field, choosing the place for beekeeping exploitation, thus eliminating the route performed in the area of the honey basis (once or twice for safety measures) prior to the moment of transhumant shepherding, the possibility to obey the distance between apiaries at honey peaks (of minimum $100 \mathrm{~m}$, and the apiary not to be on the flight direction of the bees belonging to other apiary) as the law stipulates (Legea 383/2013).

* -the certain and easy determination of the origin geographic area and of honey authenticity as it was set out in the National Beekeeping Programme from Romania for 2017-2020.

* -the estimated appreciation of the honey production $(\mathrm{kg} / \mathrm{ha}$ ) made throughout the blooming stage of the chosen honey plant, correlating the digital maps regarding the characteristics of the plant and land, at the distance / flying ray $(3 \mathrm{~km})$ till the working bees can economically capitalize the honey sources, as well as the additional information from the application;

* -the possibility of orientation. reorientation towards practicing beekeeping within the natural protected areas and disadvantaged areas (of administrative - territorial units with practices of agro environment where no pesticides are used), of promoting and sustaining ecological apiculture.

D.3) The consultancy and specialized assistance as part of volunteer work, achieved through a consultative council formed by members with scientific training or / and beekeeping producers, selected as the best and with more experience (vet, the president of the beekeepers' Association/ agricultural and apicultural entrepreneurs) have created and creates the framework of a good functioning of the subnetwork of beekeepers through:

I. finding solutions to varied issues that occurred spontaneously throughout the organisation and the carrying out of the producer's / beekeeper's activity which sometimes created momentous gridlocks (e,g. during the uncontrolled natural swarming connected with catching the natural swarm and attracting the natural bee swarms);

II. guidance / suggestions connected with investments for the growth and the modernization of the producers' business (purchasing tools / machines for maintaining and exploiting the bee families, for harvesting the apiculture products for maintaing and exploitation of the bee families, for transhumant shepherding), for attracting European funds,etc.

\section{Conclusions}

* The South East Development Region disposes of such a high melliferous potential that most responders $(98.73 \%)$ have carried out their apiculture activity within this region through the complimentary character of the component counties contributing to the binding of the apiculture production and maintenance harvests all over the season;

* The transhumance highlights the severe issues that the beekeeping has and the same time represents the way to maintaining the beekeeping as a traditional occupation and of developing business and entrepreneurship;

\$ The issues expressed by the responders - members of the network of beekeepers from The Basin of The Black Sea Region are firstly issues that refer to the apiculture / agriculture, forestry and administrative sectors from the Romanian space and which should be taken into consideration by their main actors;

* Through the project activities a set of needs identified as priorities directly connected with the activity of the beekeepers within the South East Development Region have been solved, with the increase of competitiveness and sustainability of the beekeeping sector; an eloquent example is the application that contains digital maps with the forest melliferous potential.

\section{Acknowledgments:}

This work was performed in the frame of the project "Increase trading and modernization of beekeeping and connected sectors in the Black Sea Basin", ITM BEE-BSB, BSB136, sustained through the Common Operational Programme - the Basin of the Black Sea 2014-2020, co-financed by the European Union through the European Tool of Neighbourhood and by the participant countries (Bulgaria, Moldova, Turkey and Ukraine), implemented by The Tehnopol Galati Association in March 2019.

\section{References:}

1. Alexandru V. et al. (1986). The beekeeper's textbook, the VIth edition, The Asociation of the Beekeepers from R.S.România, Bucharest.

2. Caudullo, G., Welk, E., \& San-Miguel-Ayanz, J. (2017). Chorological maps for the main European woody species. Data in brief, 12, 662666.

3. Ciuvăţ, A. L., Abrudan, I. V., Blujdea, V., Marcu, C., Dinu, C., Enescu, M., \& Nuţă, I. S. (2013). Distribution and peculiarities of black locust in Romania. Europe, 1, 601.

4. Csép, N. (2018). Sunflower in Romanian agriculture. Acta Agraria Debreceniensis, 153-163. 
5. Eaton, E., Caudullo, G., \& De Rigo, D. (2016). Tilia cordata, Tilia platyphyllos and other limes in Europe: distribution, habitat, usage and threats. European Atlas of Forest Tree Species, J. San-Miguel-Ayanz, D. De Rigo, G. Caudullo, T. Houston Durrant, und A. MAURI, (Hrsg.) Publ. Off. EU: Luxembourg. e010ec5.

6. Grigoras, M. A. (2018). Swot Analysis of Romania's Apiculture. Scientific Papers Series-Management, Economic Engineering in Agriculture and Rural Development, 18(4), 129-141.

7. Iordache, P., Roșca, P., Cismaru, M. (2007). Melliferous plants of very high and high economic-apiculture share, The Beekeeping World Publishing House, Bucharest http://www.apiflora.ro/flora_melifera/cd2/CD\%202/pag/index.htm

8. Kaya, Y. (2014). Sunflower Production in Blacksea Region: The Situation \& Problems. Agricultural Research, 4(1), 147-155.

9. Lazăr, S., Vornicul, O.C. (2007). Apiculture, Apiculture, Alfa Publishing House, Iași.

10. Nicolescu, V. N., Hernea, C., Bakti, B., Keserü, Z., Antal, B., \& Rédei, K. (2018). Black locust (Robinia pseudoacacia L.) as a multi-purpose tree species in Hungary and Romania: a review. Journal of forestry research, 29(6), 1449-1463.

11. Pîrvu C. (2000). The Universe of the plants. Bucharest: Enciclopedia, 2000.

12. Sitzia, T., Cierjacks, A., De Rigo, D., \& Caudullo, G. (2016). Robinia pseudoacacia in Europe: distribution, habitat, usage and threats. European Atlas of Forest Tree Species. Publication office of the European Union, Luxembourg, 166-167.

13. Vizireanu, F. (2020). Training in beekeeping, course notes, (for the course of the beekeepers from the Black Sea Basin Region, The South - East Development Area, Romania.

14. Asociația crecătorilor de albine din România. (1986). Manualul apicultorului, ediția a VI-a, București.

15. http://statistici.insse.ro:8077/tempo-online

16. http://www.icdapicultura.ro/wp-content/uploads/2019/01/Lege-383-2013-actualizata.pdf

17. https://ems-bs.mdrap.ro/app/main?execution=e1s1; https://www.tehnopol-gl.ro/ro

18. https://ro.beekeeping-bsb.net/harti/

19. Law no. 79/2020 for the amendment and completion of the Law of Apiculture no. 383/2013; Law no. 383/2013 from 24 December 2013; ege5.ro/Gratuit/gm3tiojsgmza/legea-nr-79-2020-pentru-modificarea-si-completarea-legii-apiculturii-nr-383-2013; http://www.icdapicultura.ro/wp-content/uploads/2019/01/Lege-383-2013-actualizata.pdf

20. Ministerul Agriculturii și Dezvoltării Rurale, Programul Naţional de Dezvoltare Rurală 2007 - 2013, versiunea consolidată noiembrie 2013; http://www.madr.ro/docs/dezvoltare-rurala/PNDR_2007-2013_versiunea-consolidata-nov2013.pdf.

21. The Asociation of Beekeepers from Romania, Apiculture Romania, no.1, January, 2019, p. 21; http://www.icdapicultura.ro/cercetaredezvoltare/genetica-si-ameliorarea-albinelor/albina-carpatina-apis-mellifera-carpatica/

22. The Ministry of Agriculture and Rural Development, "The National beekeeping programme from Romania for 2017-2019", http://www.madr.ro/programul-national-apicol.html

23. The National Statistics Institute;Bucharest http://statistici.insse.ro:8077/tempo-online 